\title{
Effectiveness of the Usage of Various Solvent in Essential Oil Production from Tuberose Flower Waste (Polianthes Tuberose L.) by Enfleurage Method
}

\author{
Arita Dewi Nugrahini*, Candra Dewa Baskara, Jumeri, Makhmudun Ainuri \\ Department of Agroindustrial Technology, Faculty of Agricultural Technology \\ Universitas Gadjah Mada, Jl. Flora No.1 Bulaksumur 55281, Indonesia. \\ Email: arita.dewi.n@gmail.com*
}

\begin{abstract}
Tuberose flower wastes are potentially used as raw materials for producing essential oils. Enfleurage method was used in the extraction process of the flower wastes. Petroleum ether and hexane were used as solvents during the extraction, while snow white (white butter) was used as fat during the enfleurage process. The enfleurage process was done for 4 days with replacement of flowers every 24 hours. It was found that petroleum ether gave higher yield than hexane (i.e. 7.07\%). However, compared with hexane, petroleum ether was still existed on the produced essential oil.
\end{abstract}

Keywords: enfleurage, hexane, petroleum ether, tuberose flower, waste

\section{INTRODUCTION}

Tuberose (Polianthes tuberosa L.), a native Mexican plant (South America) from the family Amaryllidaceae, has spread and adapted well in hot climates (tropical). In Indonesia, tuberose production is getting increased every year. According to the National Bureau of Statistics, production of tuberose flower in Indonesia has reached 104,975 million stalks in 2013.

Today, many tuberoses in Indonesia are only used as cut flowers. In the cut flower business, the waste of these flowers has no economic value because the flowers used for decoration purposes should be in fresh condition, whereas the wilted tuberose flowers had just been thrown away. Meanwhile, there are high demand and selling price for essential oils made from tuberose flowers. Further processing of the tuberose flower wastes, therefore, is an alternative to give added values. This research conducted in Kotabaru because Kotabaru is one of the central of cut flower market sellers in Yogyakarta; in addition the flowers waste is abundant and unutilized.

The purposes of this research were to find out whether waste of the tuberose flowers still contain valuable essential oil when extracted by enfleurage method, and also to find out which solvent, from two solvents used in the research, gave higher essential oil yield from tuberose flower wastes.

\section{MATERIAL AND METHODS}

The study was conducted to increase the added value of tuberose cut flowers waste in the flower market in Kotabaru, Yogyakarta. The waste is processed into tuberose flower essential oil. The process was conducted using enfleurage with fat as adsorbent.

\subsection{Material}

Raw materials used in the study were the unsold tuberose flower wastes obtained from the flower shop in Kotabaru flower market. Tuberose flower waste parts used are flower petals. Fat used as absorbent was snow white (white butter), while petroleum ether and hexane were used as solvents.

\subsection{Methods}

Enfleurage process is a method of capture flower essential oil with the use of fat as an adsorbent, where the aroma absorption by fat occurs in a state without heating (Guenther, 2011). A number of $450 \mathrm{~g}$ of fat was added to each solvent, evenly over the surface of the glass frame or chassis. Chassis used as much 
for each solvent by 2 pieces with each of the chassis as much as 225 grams of fat. Petal of the sorted tuberose flower wastes were taken and placed on a chassis that has been smeared with grease. Laid flower petals done facedown. Chassis then enter into a container that has been provided and is closed. After that leave it at room temperature. Open the chassis and tuberose flower is removed and replaced every 24 hours for 7 days. Furthermore, take the fat from the chassis. To optimize the extraction process, the rest of the replaced tuberose flowers were soaked into the solvent for 1 hour and stirred every 10 minutes. Pomade, a fat resulted from enfleurage, was dissolved into both solvents in a ratio of 1 (fat):4 (solvent). Pomade was then separated from the solvents with a funnel. The filtrate, called as absolute, and then was evaporated with vacuum rotary evaporator at $40^{\circ} \mathrm{C}$ and 170-175 mmHg.

\section{RESULTS AND DISCUSSION}

Before entering the next process, tuberose flower waste was sorted. The function of the sorting process is to get flowers that are still viable for use. The sorting process conducted in the laboratory, and performed manually by separating the petals that were still buds and wither.

Absolute yield is the ratio between the weight of essential oil obtained and material in the extraction.

Table 1. Average yield of Essential Oil from Tuberose Flowers Waste

\begin{tabular}{|l|c|}
\hline \multicolumn{1}{|c|}{ Solvents } & Average of Yield (\%) \\
\hline Petroleum ether & 7.07 \\
\hline Hexane & 5.16 \\
\hline
\end{tabular}

Table 1 shows that petroleum ether gave greater yield of essential oil. However, compared with hexane, the solvent substances were still existed on the produced essential oil.

Absolute resulting yellowish-white essential oil and has a floral scent of tuberose. Average result of tuberose extract obtained in this study is higher than Nopalas (1999), which ranged from 0.03 to $0.10 \%$. This difference was caused by different extraction process. Physically, tuberose flower used in the enfleurage process alive so the flowers can still produce essential oil and vaporize it. Steam resulted by this process will be absorbed by fat, then.

Tuberose flower waste that is used in this process is the flower that has been through the process of sorting. Preferred flower is the flower that reached almost wilted blooms that produced a high yield. Bloomed flowers produced essential oils and vaporize it during respiration that make disadvantages of this enfleurage method, which is essential oils produced could not be completely separated from the fat used.

Essential oils were produced and then analyzed their constituent components with GC-MS. Results of the analysis of essential oil of tuberose flower waste using GC-MS is shown in Figure 1.

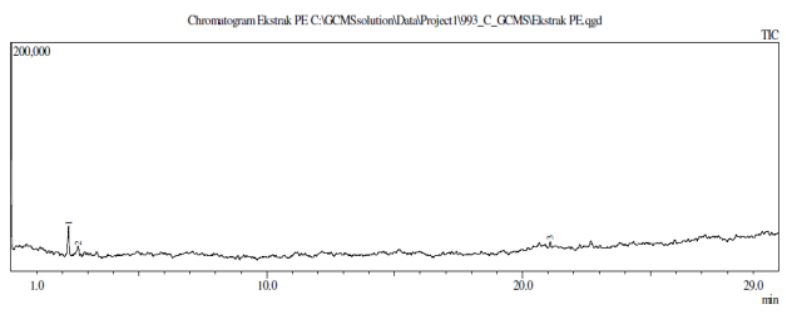

Figure 1 (a). GC-MS Analyzis of Essential Oil from Tuberose Flower Waste with Petroleum Ether Solvent

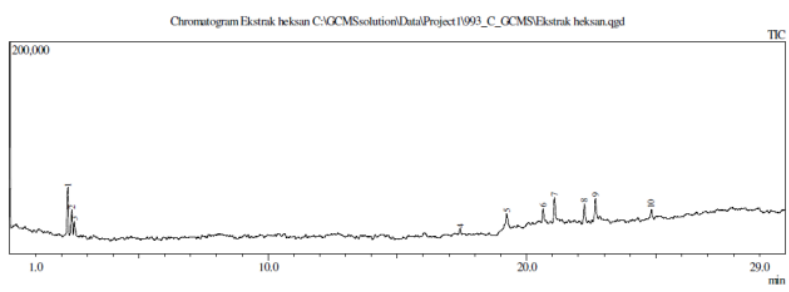

Figure 1 (b). GC-MS Analyzis of Essential Oil from Tuberose Flower Waste with Hexane Solvent

Figure 1 (a) shows that the results of the GCMS analysis of volatile oil from enfleurage process using petroleum ether solvent produced three peaks, which consists of Acetone $\left(\mathrm{C}_{3} \mathrm{H}_{6} \mathrm{O}\right)$, 3-methyl hexane $\left(\mathrm{C}_{7} \mathrm{H}_{16}\right)$, and Nonyl aldehyde $\left(\mathrm{C}_{9} \mathrm{H}_{18} \mathrm{O}\right)$. However, the content which is an essential oil was just Nonyl aldehyde, whereas 
the others are part of the solvent.

Figure 1 (b) shows that the results of the GCMS analysis of volatile oil from enfleurage process using hexane solvent produced ten peaks. Five of them are the part of solvent, and the rest, namely Methyl oleate, Eicosanol, Oleate acid, Linoleate chloride acid, and Octadecenyl aldehyde, are essential oil's composition.

\section{CONCLUSION}

Petroleum ether gave greater yield, but compared with hexane, the solvent substances were still existed on the produced essential oil.Enfleurage method with hexane as solvent, therefore, gave more pure and better quality of the produced oil.

\section{REFERENCES}

Guenther, E. 2011. Minyak Atsiri [Essential Oil]. Volume 1 (Trans.) S. Ketaren. Jakarta: Penerbit Universitas Indonesia.

Ketaren, S. 2008. Pengantar Teknologi Minyak dan Lemak Pangan [The Introduction to Food Oils and Fats Technology]. Jakarta: UI Press.

Nopalas, R. 1999. Pengaruh Waktu Ekstraksi dan Tingkat Kemekaran Terhadap Mutu Minyak Atsiri Bunga Sedap Malam Kultivar Tunggal (Polianthes tuberose vas gracilis) [The Influence of Extraction Time and Level of Flower Efflorescence against Quality of Tuberose Essential Oils of Single Cultivars (Polianthes tuberose vase gracilis)]. Bogor: Fakultas Teknologi Pertanian IPB.

Rukmana, R. 1995. Sedap Malam [Tuberose Flower]. Kanisius. Yogyakarta.

Suryani, M. 1999. Kajian Proses Produksi Minyak Atsiri Bunga Sedap Malam Tunggal (Polianthes tuberose var gracilis) Dengan Metoda Enfleurage [Production Process Study of Single Cultivar Tuberose Flower Essential Oil (Polianthes tuberose vase gracilis) by Enfleurage Method]. Bogor: Fakultas Teknologi Pertania IPB. 